\title{
Pencarian File Teks Berbasis Content dengan Pencocokan String Menggunakan Algoritma Brute force
}

\author{
Danuri \\ Jurusan Teknik Informatika, Politeknik Negeri Bengkalis \\ Email: danuri@polbeng.ac.id
}

\begin{abstract}
Abstrak
Keberadaan file menjadi penting saat dibutuhkan dan menjadi permasalahan apabila tidak ditemukan. Nama dari suatu file belum tentu memberikan gambaran isi yang terkandung pada file. Ini yang menjadi dasar dalam pencarian file berbasis konten. Terdapat beberapa algoritma untuk menyelesaikan permasalahan tersebut diantaranya algoritma brute force. Pengembangan algoritma pencarian dengan menciptakan pencarian lokal dan global memberikan kesempatan setiap kata pada file dan file pada lokasi yang dicari dapat diperiksa. Hasil pengujian menunjukkan rata-rata waktu proses 1 file sebesar 0.003847 detik dari 120 kali percobaan. Semakin banyak jumlah kata dalam suatu file dan jumlah file dalam satu tempat penyimpanan menyebabkan kebutuhan waktu semakin meningkat.
\end{abstract}

Kata Kunci: Pencarian lokal, pencarian global, algoritma brute force

\section{PENDAHULUAN}

File adalah berkas atau naskah yang disimpan pada komputer. Berkas ini dapat berupa tulisan atau teks, gambar, kumpulan instruksi program, musik video, dan sebagainya. Satu diantara aplikasi pengolah teks adalah Microsoft Office Word yang dapat menghasilkan dokumen laporan dan lain sebagainya [1]. File teks yang dihasilkan dari aplikasi tersebut diantaranya doc, docx, xls, xlsx, ppt, dan pptx.

Keberadaan suatu file sangat penting pada saat dibutuhkan. Teknik penyimpanan yang baik akan membantu dalam mempercepat proses penemuan suatu file. Namun, hal ini akan menjadi masalah apabila file yang dicari tidak disimpan secara baik seperti penamaan file yang tidak mencirikan isi dari file dan sudah lama tidak diakses sehingga daya ingat menurun terkait keberadaan file tersebut.

Dibutuhkan teknik tertentu agar file yang dicari dapat ditemukan dengan baik. Diantara teknik pencarian berupa pencocokan string antara string yang dicari dengan nama file yang tersedia di komputer. Pencarian file berdasarkan nama file belum mampu menjamin isi dari file sesuai dengan kebutuhan pengguna. Oleh karena itu, diperlukan algoritma pencarian file berdasarkan pencocokan string dengan string yang dicari dengan konten dari suatu file. Pencocokan string merupakan salah satu algoritma untuk mempercepat proses pencarian file berdasarkan string yang dimasukkan. Algoritma pencocokan string yang sering digunakan adalah algoritma brute force. Algoritma brute force adalah algoritma melakukan pencocokan string yang dinputkan dengan semua teks antara 0 dan $n-m$ untuk menemukan keberadaan string yang diinputkan dalam teks [2]. 


\section{METODE}

\subsection{Tinjauan Pustaka}

Pencarian file banyak menarik minat untuk dikaji baik dengan menerapkan algoritma brute force untuk penyelesaian permasalahan tertentu atau dengan algoritma lainnya.

Kajian tentang pencarian data katalog buku pada perpustakaan menerapkan algoritma brute force. Perpustakaan merupakan salah satu tempat yang banyak digunakan mahasiswa untuk mencari informasi di dalam memecahkan suatu masalah yang ditemui pada proses pembelajaran. Jumlah buku yang sangat banyak akan memberikan masalah dalam hal pencarian data katalog buku yang terdapat pada perpustakaan. Dalam melakukan pencarian data katalog buku perpustakaan, pencocokan string merupakan suatu bagian dalam proses pencarian string (string searching). Hasil yang dicapai dari penerapan algoritma brute force dapat melakukan pencocokan string dan memberikan hasil yang diinginkan dsesuai dengan data pencarian pada katalog buku perpustakaan dan pengunjung perpustakaan dalam melakukan pencarian terhadap katalog buku perpustakaan dapat diselesaikan dengan waktu yang singkat [2].

Algoritma brute force untuk menyelesaian permasalahan font italic untuk kata asing secara otomatis di dalam Microsoft Office Word. Algoritma brute force akan menempatkan dan mencari semua kemungkinan kata asing dengan masukan karakter dan panjang kata asing tertentu, tentunya dengan banyak sekali kombinasi dalam kalimat-kalimat. Hasilnya yaitu algoritma brute force mencoba setiap posisi pattern terhadap teks, kemudian dilakukan proses pencocokan setiap karakter dan teks pada posisi tersebut [1].

Pencarian string merupakan bagian yang sangat penting dalam beberapa masalah termasuk dalam masalah edit teks, pencarian teks dan manipulasi simbol. Pengembangan pada algoritma brute force yang diberi nama algoritma Start-EndMid. Algoritma yang diusulkan tidak melakukan pencocokan terhadap semua karakter dari string yang dicari melainkan melakukan pengecekan karakter pertama, akhir, dan tengah. Hasil pengembangan algoritma ini mempercepat proses pencarian [3].

\subsection{Landasan Teori}

\subsubsection{Dokumen digital}

Dokumen digital merupakan setiap informasi elektronik yang dibuat, diteruskan, dikirimkan, diterima, atau disimpan dalam bentuk analog, digital, elektromagnetik, optikal, atau sejenisnya, yang dapat dilihat, ditampilkan atau didengar melalui komputer atau sistem elektronik. Untuk dapat mendistribusikan melalui media web ada beberapa format standar yang digunakan, beberapa diantaranya yang sering digunakan adalah Portable Document Format (PDF), Hypertext Markup Language (HTML), eXtensible Markup Language (XML), eXtensible Hypertext Markup Language (XHTML) dan lain sebagainya [4]. Format standar hasil olahan dari software pengolah kata yaitu txt, doc, docx, xls, xlsx, ppt, dan pptx. 


\subsubsection{Pencocokan String}

Pencocokan string atau string matching adalah proses pencarian semua kemunculan string pendek $P[0 . . n-1]$ yang disebut pattern di string yang lebih panjang $T[0 . . m-1]$ yang disebut teks. Pencocokan string merupakan permasalahan paling sederhana dari semua permasalahan string lainnya, dan merupakan bagian dari pemrosesan data, pengkompresian data, lexical analysis, dan temu balik informasi. Teknik untuk menyelesaikan permasalahan pencocokan string biasanya akan menghasilkan implikasi langsung ke aplikasi string lainnya [5].

String matching adalah pencarian sebuah pattern pada sebuah teks [6]. Prinsip kerja algoritma string matching adalah sebagai berikut [7]:

1. Memindai teks dengan bantuan sebuah window yang ukurannya sama dengan panjang pattern.

2. Menempatkan window pada awal teks.

3. Membandingkan karakter pada window dengan karakter dari pattern. Setelah pencocokan (baik hasilnya cocok atau tidak cocok), dilakukan shift ke kanan pada window. Prosedur ini dilakukan berulang-ulang sampai window berada pada akhir teks. Mekanisme ini disebut mekanisme sliding-window.

Contoh sliding windows yang sedang menggeser pattern di teks dapat dilihat di Gambar 1.
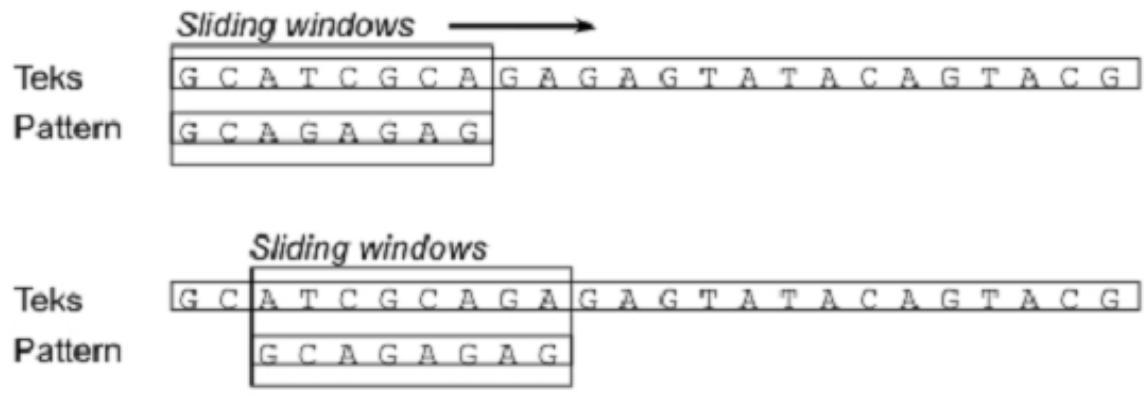

Gambar 1. Ilustrasi pergerseran pada proses pencocokan string

\subsubsection{Algoritma Brute Force}

Algoritma brute force merupakan algoritma sederhana yang dapat digunakan dalam pencarian pola. Ide dasar dari algoritma brute force adalah membandingkan karakter demi karakter antar string yang dicari dengan string sumber. Apabila tidak sesuai maka akan dilakukan penggeseran posisi dari kiri ke kanan. Demikian seterusnya sampai ditemukan string yang dicari [3].

Beberapa karakteristik dari algoritma brute force dapat dijelaskan sebagai berikut [8].

1. Membutuhkan jumlah langkah yang banyak dalam menyelesaikan suatu permasalahan sehingga jika diterapkan menjadi suatu algoritma program aplikasi akan membutuhkan banyak memori.

2. Digunakan sebagai dasar dalam menemukan suatu solusi yang lebih efektif.

3. Banyak dipilih dalam penyelesaian sebuah permasalahan yang sederhana karena kemudahan cara berpikirnya. 
4. Pada banyak kasus, algoritma ini banyak dipilih karena hampir dapat dipastikan dapat menyelesaikan banyak persoalan yang ada.

5. Digunakan sebagai dasar bagi perbandingan keefektifan sebuah algoritma.

\subsection{Metode}

Metode waterfall merupakan metode yang digunakan terdiri atas analisa permasalahan, perancangan, penulisan kode program, dan pengujian [9]. Diagram dari metode waterfall dapat dilihat pada Gambar 2.

1. Analisa permasalahan, meliputi format file yang menjadi inputan, teknik pencarian dokumen teks dengan pencocokan pola, proses indexing.

2. Perancangan perangkat lunak, meliputi perancangan perangkat lunak, perancangan antarmuka dan perancangan database.

3. Penulisan kode program, penulisan program menggunakan bahasa pemrograman PHP dan untuk pengelolaan data menggunakan DBMS MySQL.

4. Pengujian, pengujian dilakukan menggunakan metode blackbox untuk beberapa model pengujian meliputi pengujian fungsionalitas perangkat lunak, pengujian lingkungan perangkat lunak dan pengujian waktu pencarian

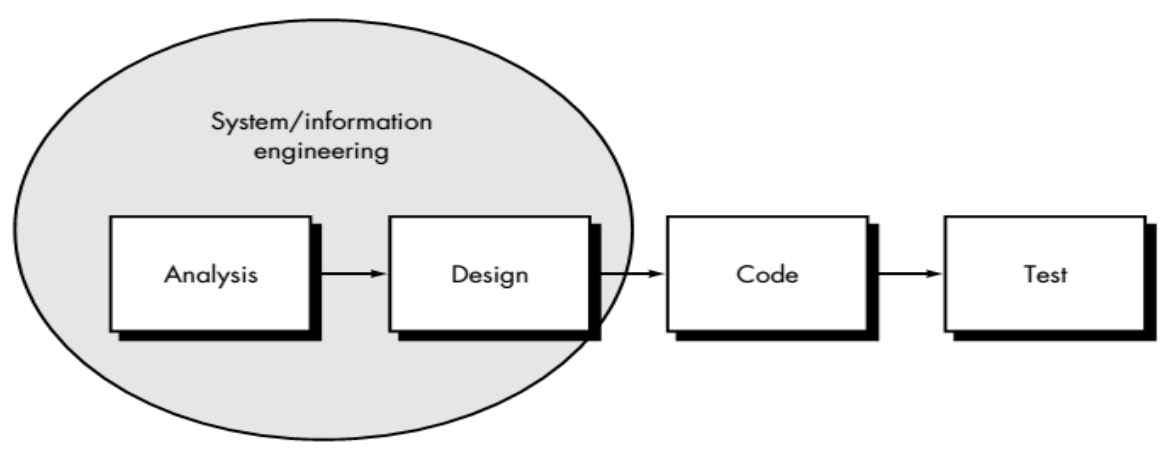

Gambar 2. Model waterfall

\section{HASIL DAN PEMBAHASAN}

\subsection{Proses Pencarian File}

Penerapan algoritma brute force untuk proses pencarian file dengan pencocokan string dapat dilihat pada Gambar 3. Proses pencarian dimulai dengan menginputkan kata kunci yang ingin dicari dan penentuan lokasi yang akan dicari. Aplikasi akan menerima inputan kemudian melakukan proses pencarian lokasi dan membaca kata kunci yang akan dicari. Pada saat lokasi ditemukan, aplikasi akan membaca isi semua file yang ada di lokasi tersebut. Terdapat batasan disini bahwa file yang dibaca merupakan file teks berekstensi txt, doc, docx, xls, xlsx, ppt, pptx dan pdf. Hasil dari pembacaan tersebut akan diketahui jumlah file yang tersedia. 
Algoritma brute force diterapkan pada 2 model pencarian yaitu pencarian global disebut dengan algoritma brute force global dan pencarian lokal disebut dengan algoritma brute force lokal.

Inti dari pencarian file terletak pada algoritma brute force lokal. Disini proses pencocokan string dilakukan antara string yang dicari dengan string yang di dalam file. Proses dimulai dengan membaca semua string didalam suatu file kemudian ditampung kedalam suatu variabel larik. Proses perbandingan dilakukan dengan membandingkan setiap karakter pada string file dengan string yang dicari. Apabila terdapat 1 karakter saja yang tidak sesuai akan dilakukan perpindahan dengan menggeser ke kanan sejauh n karakter sama seperti yang diilustrasikan pada Gambar 1. Hal ini dilakukan terus menerus sampai semua string pada file yang bersangkutan dibandingkan dengan string yang dicari. Apabila ditemukan string yang cocok, aplikasi akan memberikan informasi bahwa file yang bersangkutan terdapat string yang dicari dengan pesan ditemukan. Apabila tidak ditemukan, proses pencarian akan dilanjutkan ke file lainnya.

Pencarian pada file berikutnya diawali dengan pembacaan seluruh isi file yang dikonversi menjadi string dan dilanjutkan proses lainnya. Proses yang dilalui sama halnya pada file sebelumnya. Proses pencarian pada semua file yang ada dilokasi yang telah ditetapkan sebelumnya digolongkan sebagai algoritma brute force global. Hal ini didasarkan pada proses pembacaan semua file yang memiliki ekstensi sesuai dengan batasan yang ditetapkan dan proses pembacaan file dilakukan satu persatu sampai semua file diproses. File yang ditemukan berkemungkinan lebih dari satu karena proses pencarian dilakukan terhadap semua file yang ada.

Hasil pencarian akan menampilkan status dari masing-masing file yang terbaca. Apabila ditemukan kata kunci pada file yang bersangkutan akan ditampilkan status 'ditemukan' dan apabila tidak ditemukan akan ditampilkan status 'tidak ditemukan'. Untuk kebutuhan perhitungan waktu ditempatkan script untuk membaca waktu diawal dan akhir dari eksekusi. Waktu proses ditampilkan ke antarmuka pada bagian bawah hasil dari pencarian. 


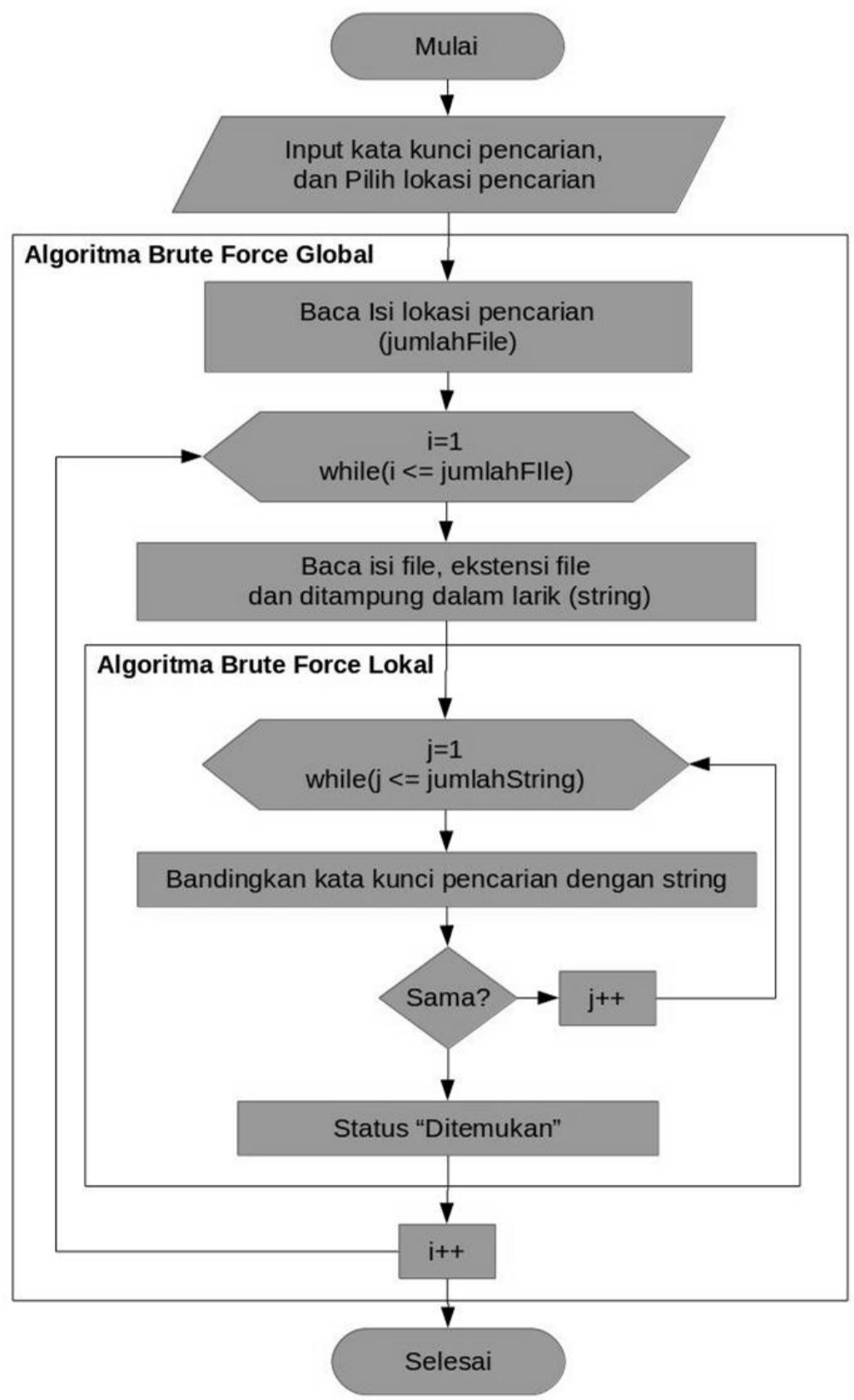

Gambar 3. Flowchart pencarian file 


\subsection{Pengujian Fungsionalitas Aplikasi}

Pengujian untuk mengetahui fungsionalitas dari setiap elemen yang ada di aplikasi. Ringkasannya dapat dilihat pada Tabel 1 .

Tabel 1. Pengujian fungsionalitas aplikasi

\begin{tabular}{|c|c|c|c|}
\hline No & Pengujian & $\begin{array}{c}\text { Hasil } \\
\text { Pengujian }\end{array}$ & Keterangan \\
\hline 1 & $\begin{array}{lr}\begin{array}{l}\text { Pengujian } \\
\text { inputan kata }\end{array} \\
\begin{array}{l}\text { (textfield) } \\
\text { kunci }\end{array}\end{array}$ & Berhasil & $\begin{array}{l}\text { Pengujian dilakukan dengan } \\
\text { kondisi textfield kosong dan } \\
\text { berisi }\end{array}$ \\
\hline 2 & $\begin{array}{l}\text { Pengujian elemen div } \\
\text { result (hasil pencarian) }\end{array}$ & Berhasil & $\begin{array}{l}\text { Pengujian dilakukan didahului } \\
\text { dengan penekanan tombol cari } \\
\text { dan diuji coba dengan perintah } \\
\text { echo }\end{array}$ \\
\hline 3 & $\begin{array}{l}\text { Pengujian } \\
\text { button cari }\end{array}$ & Berhasil & $\begin{array}{l}\text { Pengujian dilakukan dengan } \\
\text { proses pemberian aksi }\end{array}$ \\
\hline
\end{tabular}

Dari pengujian diperoleh semua elemen yang ada di aplikasi dapat difungsikan sesuai dengan peruntukannya.

\subsection{Pengujian Lingkungan Perangkat Lunak}

Ditujukan untuk mengetahui apakah hasil rancangan kompatibel terhadap web browser. Pengujian dilakukan dengan menjalankan aplikasi di beberapa web browser. Ringkasannya dapat dilihat pada Tabel 2.

Tabel 2. Ringkasan pengujian eksperimen kedua

\begin{tabular}{cccl}
\hline No & Web browser & \multicolumn{1}{c}{ Hasil } & \multicolumn{2}{c}{ Keterangan } \\
\hline 1 & Mozilla firefox & Bisa dijalankan & $\begin{array}{l}\text { Aplikasi dapat dijalankan dan } \\
\text { tidak memerlukan plugin } \\
\text { tambahan } \\
\text { Aplikasi dapat dijalankan dan } \\
\text { tidak memerlukan plugin } \\
\text { tambahan }\end{array}$ \\
& IE & Bisa dijalankan & $\begin{array}{l}\text { Aplikasi dapat dijalankan dan } \\
\text { tidak memerlukan plugin } \\
\text { tambahan }\end{array}$ \\
\hline
\end{tabular}

Dari pengujian dapat diperoleh aplikasi mampu berjalan di 3 web browser yaitu Mozilla firefox, IE, dan chrome.

\subsection{Pengujian Waktu Pencarian}

Pengujian dilakukan untuk mengetahui performa algoritma dalam melakukan proses pencarian file. Ringkasannya dapat dilihat pada Tabel 3. 
Tabel 3. Ringkasan pengujian waktu pencarian

\begin{tabular}{ccc}
\hline No & Jumlah File & Rata-rata Waktu Proses (detik) \\
\hline 1 & 1 & 0.005222 \\
2 & 5 & 0.017725 \\
3 & 10 & 0.021865 \\
4 & 15 & 0.063194 \\
5 & 20 & 0.081426 \\
\hline
\end{tabular}

Pengujian dilakukan terhadap file dengan format doc, docx, xls, xlsx, ppt, pptx, pdf, dan txt. Pengujian dengan melakukan percobaan 3 kali untuk setiap jenis format file. Hasil yang diperoleh menunjukan performa algoritma yang diterapkan dalam aplikasi rata-rata waktu proses 1 file sebesar 0.005222 detik sehingga apabila dirasiokan dari 120 kali percobaan untuk eksekusi 1 file membutuhkan waktu 0.003847 detik.

\section{SIMPULAN}

Pencarian berbasis konten pada file teks dapat dilakukan dengan menggunakan algoritma brute force. Pengembangan algoritma pencarian dengan menciptakan pencarian local dan global memberikan kesempatan semua file dapat dibaca dan diperiksa memenuhi kriteria pencarian. Semakin banyak file didalam suatu folder atau tempat pencarian semakin besar waktu yang dibutuhkan.

\section{REFERENSI}

[1] Saragih, M.A. 2013. Implementasi Algoritma Brute Force dalam Pencocokan Teks Font Italic untuk Kata Berbahasa Inggris pada Dokumen Microsoft Office Word. Pelita Informatika Budi Darma. Vol. 4(3): 84-87

[2] Mesran. 2014. Implementasi Algoritma Brute Force dalam Pencarian Data Katalog Buku Perpustakaan. Informasi dan Teknologi Ilmiah (INTI). Vol. 3(1): 100-104

[3] Abdeen, R.A. 2011. An Algorithm for String Searching Based on Brute-Force Algorithm. International Journal of Computer Science and Network Security (IJCSNS). Vol. 11(7): 24-27

[4] Haryanto, B. 2009. Sistem Operasi. Informatika : Bandung

[5] Breslauer, D. 1992. Efficient String Algorithmics. PhD Thesis. Computer Science Department. Columbia University

[6] Rasool, A., Tiwari, A., Khare, G.S.N. 2012. String Matching Methodologies: A Comparative Analysis. International Journal of Computer Science and Information Technologies ((IJCSIT). Vol.3(2): 3394 - 3397

[7] Efendi,D., Hartono.T., Kurnaedi,A. 2013. Penerapan String Matching menggunakan Algoritma Boyer-Moore pada Translator Bahasa Pascal ke C. Majalah Ilmiah UNIKOM. Vol.11(2):262-275

[8] Munir,R. 2005. Algoritma dan Pemrograman dalam Bahasa Pascal dan C. Edisi 3. Informatika. Bandung

[9] Pressman, R.S. 2011. Software Engineering a Practitioner's Approach. $5^{\text {th }}$ Edition. Mc Graw Hill. New York - USA 